\title{
SUSPECT DETENTION DURING THE PRE-INVESTIGATION PROCEEDINGS IN REPUBLIC OF SERBIA
}

\begin{abstract}
According to the Article 27, paragraph 1 of the Constitution of Republic of Serbia (2006), the right to liberty is guaranteed to all domestic and foreign persons, which is derived from the constitutional provision that the holder of this right is "everyone". Everyone has the right to move freely, to settle in Republic of Serbia, to leave it, and to return to it. This freedom may be restricted by law if it is necessary to conduct a criminal proceedings, protect the public order and peace, prevent the spread of infectious diseases, or defense of Republic of Serbia (the Constitution of Republic of Serbia, 2006, the Article 39, paragraph 2). Deprivation of liberty is allowed only for legal reasons and in the procedure provided by law. Both minors and adults may be deprived of their liberty. A person who has not reached the age of 14 is considered a child, and he/she cannot be deprived of liberty in the pre-investigation procedure because, according to our legal regulations, children are not subject to criminal liability. The aim of this paper will be to explore the concept of deprivation of liberty by arresting and/or detaining a suspect in the pre-investigation procedure according to the criminal procedure legislation of Republic of Serbia, with examples from previous practice and a proposal for some legal improvements.
\end{abstract}

Keywords: arrest, detention, Police, Public Prosecutor, detention order.

\footnotetext{
* LLM, A legal trainee with Petar Jelić Law Office in Bor, a doctoral student at the Faculty of Law for Commerce and Judiciary, the University of Business Academy in Novi Sad, Serbia, e-mail: ljprica@mts.rs
} 


\section{Introduction}

Restriction of a person's freedom in the Republic of Serbia is possible in accordance with several legal texts, but in this paper, we will deal with the restriction of a person's freedom following the Criminal Procedure Code (hereinafter: The Code). According to the Code, for a person's freedom to be restricted, both material and formal conditions must be met. Material conditions imply that detention may be ordered against a person for whom grounded suspicion exists, indicating that he/she has committed a criminal offense for which prosecution is undertaken ex officio, while the formal conditions are prescribed by the applicable Code. Deprivation of liberty is "a measure aimed at creating conditions for successfully undertaking a series of actions in the phase of clarifying and proving a criminal offense, making and executing a decision in this regard, and preventing the further criminal activity of the perpetrator, in this way, deprivation of liberty is an integral part of the criminal procedure" (Matijević \& Marković, 2013, p. 159). The law defines deprivation of liberty as an arrest, keeping in custody, prohibition of leaving an abode, detention, and a stay in an institution which is under this Code counted into detention (Criminal Procedure Code, 2011, art. 2 para. 1, item 23). Custody and prohibition of leaving an abode are some of the measures that can be taken against the defendant to ensure his presence and for the uninterrupted conduct of criminal proceedings, and a stay in an institution which, under the Code, is included under detention, for a certain period.

First of all, it is important to note that the pre-investigation procedure is the first phase of the preliminary procedure, because "the preliminary procedure has its three phases", and "is initiated when there is reasonable doubt that a crime has been committed" (Matijašević-Obradović, 2016, p. 43). A suspect is a person against whom a competent public authority has undertaken a certain act stipulated under the Criminal Procedure Code in the pre-investigation proceedings due to the existence of grounds of suspicion that he committed a criminal offense and a person against whom an investigation is being conducted (Criminal Procedure Code, 2011, art. 2 para. 1 item 1). Various entities can participate in this phase of the procedure, such as state bodies, services, inspections, supervisory bodies, legal entities, as well as citizens who file criminal charges, but the most important subjects of the pre-investigation procedure are the public prosecutor and the police. The public prosecutor leads the pre-investigation procedure. "Leading means a set of actions that the public prosecutor undertakes by directing the activities of all subjects towards solving crimes and indicting their perpetrators" (Majić, 2016, p. 27). The main 
goal of this stage of the procedure, "uncovering and obtaining evidence". The search and uncovering actions that are undertaken in the pre-investigation procedure do not have criminal procedural features, because they are not performed according to the rules of criminal procedure, but according to criminal techniques and tactics. "The evidentiary actions taken in the pre-investigation procedure are identical to the evidentiary actions in the criminal procedure, regardless of whether they are undertaken by the public prosecutor or the police" (Bejatović, 2016, pp. 377-378).

Although the public prosecutor leads the pre-investigation procedure based on Art. 43 para. 2 item 1) and Art. 285 para. 1 of the Criminal Procedure Code, the police have some independent authority to take certain measures if there are grounds to suspect that a criminal offense has been committed for which prosecution is undertaken ex officio. The main purpose of the actions taken by the police in this phase of the procedure is: catching the perpetrators of the crime, preventing the perpetrator or accomplice from hiding or fleeing, obtaining and providing evidence, as well as collecting information that may be relevant in the further course of the procedure. The activities of the police are legally determined, but when performing them, if the police take certain evidentiary actions, they are carried out per the applicable provisions of the Code. Evidence gathered in this way can be used in the further course of the proceedings. The police shall inform the competent public prosecutor about the undertaken evidentiary actions, without delay, and no later than 24 hours after they are undertaken.

\section{Arrest}

The arrest of a person, if there is a reasonable doubt that he has committed a crime, is possible in the pre-investigation procedure, but after the initiation of criminal proceedings. Depending on the stage of the criminal proceedings, the arrest is made based on a decision of the pre-trial judge or a decision of the criminal council, which is not the case in pre-investigation proceedings. During the arrest, "the police does not make a special decision, so it is not possible to file a special legal remedy against this action. Control of the legality of police actions is scrutinized in the further stages of the criminal procedure" (Ilić, Majić, Beljanski \& Trešnjev, 2018, p. 769).

The current Code distinguishes between police arrest and the so-called citizens' arrest which creates wider possibilities in terms of arresting the perpetrator caught in the criminal act. A citizen's arrest encompasses "the authority of any person to arrest a person caught committing a crime" (Ilić et 
al., 2018, p. 771). Detention of a person during the commission of a criminal offense implies a situation: 1) in which the arrested person is noticed during the commission of a criminal offense, 2) in which the arrested person tries to escape after the committed criminal offense, 3 ) in which the arrested person tries to escape after the criminal offense, with the seized object. The arrested person will be taken to the public prosecutor or the police immediately, and if that is not possible, one of those authorities must be notified immediately and will act under the provisions of the Code (Criminal Procedure Code, 2011, art. 292). The police will take the arrested person to the public prosecutor without delay, and the public prosecutor will interrogate the arrested person.

The police may arrest a person if there are any of the reasons for ordering detention specified in Art. 211 of the Criminal Procedure Code (2011). Which menas that, detention may be ordered against a person for whom there exists grounded suspicion that he has committed a criminal offence if: 1) he is in hiding or his identity cannot be established or in the capacity of defendant he is clearly avoiding appearing at the trial or if there exist other circumstances indicating a flight risk; 2) there exist circumstances indicating that he will destroy, conceal, alter or falsify evidence or traces of a criminal offence or if particular circumstances indicate that he will obstruct the proceedings by exerting influence on witnesses, accomplices or concealers; 3 ) particular circumstances indicate that in a short period of time he will repeat the criminal offence, or complete an attempted criminal offence, or commit a criminal offence he is threatening to commit; 4) the criminal offence with which he is charged is punishable by a term of imprisonment of more than ten years or a term of imprisonment of more than five years for a criminal offence with elements of violence, or he has been sentenced by a court of first instance to a term of imprisonment of five years or more, and the way of commission or the gravity of consequences of the criminal offense have disturbed the public to such an extent that this may threaten the unimpeded and fair conduct of criminal proceedings. Then the arrest is "a factual measure about which the police does not make any official decision" (Bejatović, 2016, p. 386). The police are obligated to take the arrested person to the competent public prosecutor without delay. When the suspect is brought in, the police submit a report to the public prosecutor on the reasons and the time of the arrest. If the processing of the arrested person to the prosecutor due to unavoidable obstacles lasted more than eight hours, the police are required to explain the delay in detail to the public prosecutor, about which the public prosecutor will draft an official note. The public prosecutor will enter in the note the arrested person's statement about the time and place of the arrest (Criminal Procedure Code, 
2011, art. 291 para. 3). It follows from the above that the police are obliged to submit a report to the public prosecutor on the reasons and time of arrest only if they took the arrested person to the public prosecutor within 8 hours, counting from the time of the arrest to the time when the arrested person was taken to the public prosecutor. Otherwise, the police have no obligation to compile a report, but the statement of the arrested person about the time and place of arrest is entered in the official note of the public prosecutor, and the police must explain to the public prosecutor a longer period of processing than one prescribed by law. Therefore, this provision is not about the maximum time allowed for the bringing in of an arrested person to the competent public prosecutor in regular circumstances, because the bringing in of the arrested person to the competent public prosecutor is carried out without delay. In this way, "possible illicit actions of police officials in the pre-investigation procedure" are prevented and eliminated, as well as the later reference of the defendant to "irregularities which were missed in the earlier stages of the procedure" (Ilić, et al., 2016, p. 770).

The arrested person must be instructed on the rights under Art. 69 para. 1 of the Criminal Procedure Code (2011), which is first communicated to him by the police, which is to: 1) be informed immediately in a language he understands of the reason for his arrest; 2) have before his first interrogation a confidential conversation with his defense counsel, which can be supervised only visually, but not by way of listening; 3 ) demand that a family member or other person close to him be notified without delay about his arrest, as well as a diplomatic and consular representative of the state of which he is a national, or a representative of an authorized organization of international public law, in case of a refugee or a stateless person; 4) demand that he be examined without delay by a physician of his own choosing, and if that physician is not accessible, by a physician designated by the public prosecutor or the court. 5 ) not to say anything, to refrain from answering a certain question, to present his defense freely, to admit or not to admit his culpability; 6) to defend himself on his own or with the professional assistance of a defense counsel, in accordance with the provisions of this Code; 7) to have a defense counsel attend his interrogation; 8) to read immediately before his first interrogation the criminal complaint, the crime scene report, and the findings and opinions of an expert witness.

The public prosecutor is required to advise an arrested person brought before him about the rights referred to in Article 69 paragraph 1 of this Code and to make it possible for him to use a telephone or other electronic message communicator, in his presence, to notify a defense counsel directly or through 
members of the family or a third person whose identity must be revealed to the public prosecutor, and if necessary, also to assist him to find a defense counsel (Crimnal Procedure Code, 2011, art. 293 para. 1). The public prosecutor shall instruct the arrested person for the first time about his rights in a situation when a civil arrest has taken place or in a situation when an authorized police officer has failed to provide an instruction to the arrested person about his rights. If the arrested person does not secure the presence of a defense counsel within 24 hours of the time when it was made possible to him within the meaning of paragraph 1 of this Article or declares that he does not wish to obtain a defense counsel, the public prosecutor is required to question him without delay. If in the case of mandatory defense (Article 74) the arrested person does not obtain a defense counsel within 24 hours of the time he was advised of this right or declares that he will not obtain a defense counsel, an ex officio defense counsel will be appointed for him (Criminal Procedure Code, art. 293 items 2 and 3). The defendant must have a defence counsel: 1) if he is mute, deaf, blind or incapable to conduct his own defence successfully - from the first interrogation until the final conclusion of the criminal proceedings; 2 ) if the proceedings are being conducted in connection with a criminal offence punishable by a term of imprisonment of eight years or more - from the first interrogation until the final conclusion of the criminal proceedings; 3 ) if he has been taken into custody, or prohibited from leaving his abode, or is in detention - from the moment of deprivation of liberty until the ruling discontinuing the measure becomes final; 4) if he is being tried in absentia - from the issuance of a ruling on an in absentia trial and for the duration of such trial; 5) if the trial is being held in his absence due to reasons he himself induced - from the issuance of a ruling for the trial to be held in absentia until the ruling by which the court establishes that reasons for his inability to stand trial have ceased becomes final; 6) if he has been removed from the courtroom for disturbing the order, until the conclusion of the evidentiary procedure or the termination of the trial - from the issuance of the order on his removal until his return to the courtroom or the pronouncement of the judgment; 7) if proceedings for pronouncing a security measure of compulsory psychiatric treatment are being conducted against him - from the submission of a motion for pronouncing such a measure until the issuance of the decision referred to in Article 526 paragraphs 2 and 3 of this Code or until the ruling pronouncing a security measure of compulsory psychiatric treatment becomes final; 8) from the beginning of the negotiations with the public prosecutor on the conclusion of the agreement referred to in Article 313 paragraph 1, Article 320 paragraph 1 and Article 327 paragraph 1 of this Code, until the issuance of a 
court decision on the agreement; 9) if the trial is held in his absence (Article 449 paragraph 3) - from the moment of adoption of the ruling to hold the trial in his absence, to the adoption of the judicial decision on the appeal against the judgment (Criminal Procedure Code, 2011, art. 74). Having in mind the above-mentioned and the stage of the procedure, the obligatory defense of the arrested person exists in a situation if he is mute, deaf, blind, or incapable of successfully defending himself, or if the procedure is conducted due to a criminal offense punishable by 8 years of prison or more. The right to have a third person informed of the suspect's arrest, the right to a lawyer and the right to a medical examination by a doctor of the detainee's choice is, in the CPT's ${ }^{1}$ view, three basic safeguards against ill-treatment of detainees that should be applied from the start, regardless of the reasons on which that deprivation of liberty was determined. (European Committee for the Prevention of Torture and Inhuman or Degrading Treatment or Punishment (CPT), 2007, p. 6). At the request of the arrested person, a member of his family, defense counsel, or ex officio, the public prosecutor may order a medical examination of the arrested person. The decision on determining the doctor who will perform the examination is added to the case file. After the examination, the public prosecutor makes a record of the statement of the doctor who examined the arrested person, which is also added to the case file.

The public prosecutor will interrogate the arrested person following the provisions of the Code on questioning the arrested person, and will immediately after the questioning decide whether to release the arrested person or to propose detention to the pre-trial judge. A motion to order detention shall be submitted in writing to the competent pre-trial judge on the grounds that the public prosecutor is not authorized to independently order detention for the arrested person. This written document contains data on the person whose detention is proposed, the reasons that justify the submitted proposal, as well as data that indicate the existence of one or more reasons for ordering detention prescribed by Art. 211 of the Criminal Procedure Code (2011), which the public prosecutor considers valid. The submitted proposal for ordering detention must clearly state the existence of reasonable doubt as a higher degree of doubt, as required by the Constitution of the Republic of Serbia (2006), in Art. 30 para. 1. If there is no reasonable doubt that the arrested person is the perpetrator of the criminal

\footnotetext{
${ }^{1}$ The CPT is a Committee established by the Convention for the Prevention of Torture and Inhuman or Degrading Treatment or Punishment, which, through visits to persons deprived of their liberty, examines how they are treated with the aim of increasing the protection of those persons from torture and inhuman or degrading treatment or punishment. Serbia and Montenegro ratified this Convention in 2003.
} 
offense for which he is being prosecuted ex officio, the public prosecutor shall release the arrested person. A person arrested without a court decision must be handed over to the competent pre-trial judge or released without delay or within 48 hours at the latest. The same situation is with the person who was arrested based on a court decision, but who was not questioned, all in accordance with Art. 69 para. 2 of the Criminal Procedure Code (2011). It follows from the above that the detention of the suspect is limited to a maximum of 48 hours since this right is guaranteed to the person deprived of liberty by Art. 29 para. 2 of the Constitution of the Republic of Serbia (2006).

\section{Custody}

According to the Code, both suspects and citizens can be detained. First of all, the authority conducting proceedings may take into custody a person found at the location of the examination under the conditions stipulated in Article 290 of the Code (Criminal Procedure Code, 2011, Article 136, paragraph 2). Crime scene processing (examination) is an urgent investigative action that consists of direct sensory observation, clarification and determination of facts and circumstances that are important for shedding light on a specific criminal event. According to the Criminal Procedure Code, crime scene processing is a criminal-procedural action, but also a criminologilac action according to the content and technology of implementation (Matijević \& Marković, M, 2013, p. 176). However, the police may take persons found at a crime scene to a public prosecutor or hold them until his arrival, if those persons could provide data of importance for the proceedings and if it is probable that their questioning could subsequently not be performed or would entail substantial delays or other difficulties (Criminal Procedure Code, 2011, art. 290). Detention of a person at the place of investigation or the place of commission of a criminal offense may last for a maximum of 6 hours.

Detention and temporary restriction of the freedom of movement of minors, as one of the police powers, is regulated in more detail by the Rulebook on the manner and conditions of application of police powers against minors (2019), which was adopted based on Art. 70 para. 6 of the Law on Police (2016), with the consent of the Minister of Justice. An integral part of this Rulebook is Form 1 - Notice on the rights of minors in the pre-investigation procedure, which we consider an important document, so that in the Republic of Serbia all police officers trained in work with minors or other police officers trained to work with children and youth act equally, and all juveniles in the pre-trial procedure are identically informed of their rights. 
The public prosecutor may exceptionally keep in custody for questioning, not more than 48 hours from the time of the arrest, or the response to a summons the person who is: 1) a suspect who was arrested by the police when they assessed that there were legal reasons for ordering detention, 2) a suspect who was arrested by citizens during the commission of a criminal offense and immediately handed over to the police or the public prosecutor, 3) a suspect who was summoned in that capacity by the police and who responded to that summons, and for whom there are grounds for reasonable doubt that he is a perpetrator of a criminal offense or against whom actions have been taken in the pre-investigation procedure provided by the Code, 4) to a suspect who acquired that capacity during the collection of information, and was previously summoned by the police in the capacity of a citizen. It follows from the above that detention can be ordered, both against persons for whom there is a reasonable doubt that they have committed a crime, and against persons for whom there are grounds for suspicion.

However, it is debatable from which hour the time of detention is calculated for a suspect who acquired that status during the collection of information, and was previously summoned by the police as a citizen (Criminal Procedure Code, 2011, Article 289, paragraph 2). This is since the collection of information from the summoned person can take as long as it is necessary to obtain the relevant information, and for a maximum of 4 hours, and with the consent of the person giving the information even longer. Although Art. 32 of the Rulebook on Police Powers (2019) stipulates that the time of detention is counted from the moment of responding to the summons when the conditions for detention in criminal proceedings have been met, it is considered an insufficient legal source for the reason that it is a bylaw. The legislator did not determine the time of calculating the deprivation of liberty of a citizen who acquired the status of a suspect during the collection of information, and we believe that for the legal security of the suspect and equal treatment of everyone by public prosecutors and police, it is necessary to prescribe that detention time-frame is to be counted from the hour of responding to the police summons.

The public prosecutor, or upon his authorization, the police, issues and serves a custody ruling immediately, or not more than two hours after the suspect was told that he would be kept in custody (Criminal Procedure Code, art. 294 para. 2). This specifically means that the detention of a suspect in the preinvestigation procedure is realized exclusively by the decision of the public prosecutor when there is a certain reason for that as a material condition. The formal condition for detaining a suspect in the pre-investigation procedure 
implies "deciding on detention" (Škulić, 2017, p. 250). This, in turn, means that the police cannot decide on their own to keep the suspect in custody in the pre-investigation procedure. The custody decision is made exclusively by the public prosecutor. Detention of a suspect that is not following the provision of Art. 294 of the Criminal Procedure Code (2011) is illegal and represents "the basis for filing a lawsuit for damages in terms of Art. 200 of the Law on Contracts and Torts (1978) expressed in the decision of the District Court in Požarevac, Gž. No. 884/00 of 26 September 2002" (Ilić et al., 2018, p. 775).

In the jurisprudence so far, we have noticed that in some decisions on detention, made by the police, with the approval of the public prosecutor, it is stated that according to Art. 211 st. 1 items 2) and 4) of the Criminal Procedure Code (2011) decided as in the dispositive, after which the public prosecutor submits to the judge in the pre-investigation procedure a proposal to order custody against the same suspect only based on Art. 211 st. 1 item 2) of the Criminal Procedure Code (2011). We also noticed a different situation, in the decision on detention, made by the police, with the approval of the public prosecutor, it was stated that under Art. 211 para. 1 items 2) and 4) of the Criminal Procedure Code (2011) it was decided as in the dispositive, and then the public prosecutor submits to the judge for the pre-investigation procedure a proposal to order custody against the same suspect based on Art. 211 para. 1 items 1), 2) and 3) of the Criminal Procedure Code (2011). Having in mind everything mentioned above, we rightly ask in what way the detention of the suspect determined in the decision was canceled, based on Art. 211 para. 1 item 4) of the Criminal Procedure Code (2011). We further ask ourselves, what kind of approval of the public prosecutor was given to the police, if the reasons for ordering detention are prescribed by Art. 211 of the Criminal Procedure Code (2011), and how they differ in the decision on detention of the suspect, issued by the police and in the proposal for detention ordered by the public prosecutor to the judge for the preliminary procedure.

Based on the above, we believe that it would be more expedient to legally determine the rights of the suspect and the legality of the procedure of detention if only the public prosecutor was allowed to decide on custody and detention, immediately, and no later than 2 hours after the suspect was informed, detained and delivered a decision on detention, for the reason that only the public prosecutor has the power to lead the pre-investigation procedure.

The decision on detention must contain the act for which the suspect is charged, the grounds for suspicion, the day and hour of deprivation of liberty or responding to the summons, as well as the time of the beginning of detention (Criminal Procedure Code, 2011, art. 294 para. 2). However, 
the Constitutional Court in decision Už-1120/2020 from $14.07 .2010,{ }^{2}$ by which the Court adopted the applicant's constitutional complaint and established a violation of the right to liberty and security under Art. 27 st. 1 of the Constitution of the Republic of Serbia (2006) emphasized that the competent courts are obliged to explain in detail the reasons for detention or custody when deciding on deprivation of liberty, in case they determine that there are reasons for depriving a suspect of liberty. Arbitrary deprivation of liberty exists when the competent authorities do not satisfactorily explain the reasons why the deprivation of liberty was necessary. The above stated is also established in the judgment of the European Court of Human Rights, Kay v. Great Britain, application no. 17821/91, ${ }^{3}$ dated March 1 ${ }^{\text {st, }}$ 1994, paragraph 31.

The Supreme Court of Cassation (2014) also pointed out that the explanation of the decision on detention was made in the sense of Art. 294 para. 1 of the Criminal Procedure Code issued by the public prosecutor, in addition to other elements provided in para. 2, must also have substantiated grounds for detention since the police arrest referred to in Art. 291 para. 1 of the Criminal Procedure Code (2011) as one of the grounds for making this decision, possible only "if there are reasons for ordering detention (Article 211)".

In reality, we have noticed that most decisions on detention are made without a legal reason why the suspect is detained and that the most common explanation for detention is "for questioning". The dispositive of these decisions only stipulates that the suspect is to be detained for up to 48 hours. Based on the above, we believe that by the public prosecutor or with his approval, the police showcases an arbitrary action of these bodies in the preinvestigation procedure, which violates the human rights of the suspect.

Also, we agree with the Initiative to amend the Criminal Procedure Code, number 15-32-12/ 2017, part. No. 42557 from 20.11.2017., which the Protector of Citizens submitted to the Government and the National Assembly of the Republic of Serbia, in the sense that the mandatory elements of the decision to detain are "reasons for the exceptional postponement of the hearing for up to 48 hours", especially because the suspect or arrested person has the right not to say anything. If the suspect will defend himself in the further course of the procedure by "silence", then the purpose of his detention for questioning will not be realized.

\footnotetext{
${ }^{2}$ Odluka Ustavnog suda broj Už-1120/2020 od 14.07.2010. godine [Decision of the Constitutional Court no. Uz-1120/2020]. Službeni glasnik RS, no. 69/10.

${ }^{3}$ Kay v. The United Kingdom, case no. 17821/91 (1994)
} 
It has been pointed out in the literature so far that there is a "failure of the legislator to regulate the conditions and the procedure of making a decision on detention and the form of the decision to release the suspect" (Duzlevski \& Pantelić, 2020, p. 70).

As soon as the public prosecutor or, with his approval, the police decide on detention, the suspect must have a lawyer. If the suspect himself does not provide a defense counsel within 4 hours, the public prosecutor will provide him with one ex officio, in the order from the list of lawyers submitted by the competent bar association (Criminal Procedure Code, 2011, art. 294 para. 5). The defense attorney is assigned ex officio by the Serbian Bar Association, starting from February $18^{\text {th }}, 2019$. Year, so that the authorized person of the procedural body calls the Call Center and receives from the operator the name of ex-officio defense counsel, based on the Protocol on data exchange in the procedure of appointing ex-officio defense counsel (2019) signed between the Ministry of Justice, Supreme Court of Cassation, Republic Public Prosecutor's Office and the Serbian Bar Association.

The suspect and his defense counsel have the right to appeal against the decision on detention within 6 hours from the delivery of the decision. The appeal does not delay the execution of the decision. The pre-trial judge decides on the appeal within 4 hours of receiving the appeal (Criminal Procedure Code, 2011, art. 294 para. 3). If the detained person wishes to file an appeal against the decision on detention, the police officer is obliged to enable its preparation under constant supervision to prevent an attack or self-harm of the detained person. An appeal against the decision is kept in a sealed envelope by the police officer which he submits to the pre-trial judge without delay (Rulebook on Police Powers, 2019, art. 34 para. 1 and 2). The defense counsel of the detained person may submit the appeal to the police, and the police officer shall act in the same manner as with the appeal submitted by the suspect, under Art. 34 para. 3 of the Rulebook on Police Powers (2019).

The Protector of Citizens in performing the tasks of the National Mechanism for the Prevention of Torture is under Art. 19 para. 1 point c) of the Law on Ratification of the Optional Protocol to the Convention against Torture and Other Cruel, Inhuman or Degrading Treatment or Punishment (2011), proposed that the provision of Art. 34 of the Rulebook on Police Powers (2019) needs to be amended so that the police officer issues a confirmation of receipt of the complaint which will contain the day, hour, and minute of reception, as proof that the detained person handed it over to the administrative body in whose power he is. In this way, the exercise of the right to appeal would be ensured and judicial control of detention would be 
enabled.This recommendation has not yet been implemented in the Rulebook on Police Powers (2019), but we believe that it is of special importance due to the exercise of the rights of a detained person.

\section{Conclusion}

The main subjects participating in the pre-investigation procedure, as the competent bodies of the procedure, are the public prosecutor and the police. The public prosecutor leads the pre-investigation procedure, undertakes all necessary actions to prosecute the perpetrators of the criminal act, and is also authorized to take over police work that the police undertook independently based on the law. Deprivation of liberty of a person in the pre-investigation procedure in the Republic of Serbia, according to the valid Code, is possible by arrest and detention. For deprivation of liberty to be lawful, formal and material conditions must be met. The formal conditions are prescribed by the Code, and the material conditions imply that there is a certain degree of doubt that a criminal offense has been committed.

The Criminal Procedure Code (2011) recognizes the police arrest of a person when there is a legal reason for detention, as well as the arrest during the commission of a crime that can be undertaken by any citizen, with the obligation to immediately hand over the arrested person to the public prosecutor or police. The handing over of the arrested person to the competent public prosecutor by the police may take longer than 8 hours, but only due to onerous obstacles. The public prosecutor may, only exceptionally, detain the aforementioned persons who have been arrested for questioning, as well as persons who have voluntarily responded to a police summons, a suspect who has been summoned in that capacity, but also a citizen who has been summoned for questioning and that has on that occasion acquired the status of a suspect, for up to 48 hours, counting from the hour of arrest, or responding to the summons. Therefore, it follows from the above-mentioned that a person against whom there is a reasonable doubt that he has committed a criminal offense can be detained, but also a person against whom there are grounds for suspicion that he is a perpetrator of a criminal offense. While writing this paper, we found that the Criminal Procedure Code (2011) explicitly prescribes in Art. 293 para. 4 that the public prosecutor will, immediately after the hearing, decide whether to release the arrested person or to propose custody to the pre-trial judge. There is no such provision of the Code, which would also refer to the suspect who was questioned before the competent public prosecutor. 
Accordingly, we believe that the Criminal Procedure Code (2011) should be amended so that the public prosecutor will be obliged to decide immediately after hearing the suspect whether to release him or to propose custody to the pre-trial judge because there is even the lowest degree of certainty that he is the perpetrator of a criminal offense. This is because the action of the public prosecutor in the form of a decision on detention restricts the suspect's right to freedom and security guaranteed by the Constitution. We propose an amendment to the Criminal Procedure Code (2011) for the reason that the public prosecutor is obliged to, based on Art. 20 para. 3 of the Constitution of the Republic of Serbia (2006), to take into account the essence of the restricted right, the importance of the purpose of the restriction, the nature and scope of the restriction, the relationship of the restriction with the purpose of the restriction and whether there is a way to achieve the purpose with a less severe method. Any detention of a suspect by the public prosecutor in the pre-trial procedure, which is not necessary, constitutes an unlawful violation of human rights.

\section{Prica Ljubica}

Master prava, pripravnik u Advokatskoj kancelariji Petra Jelića u Boru, doktorand na Pravnom fakultetu za privredu i pravosuđe, Univerzitet Privredna akademija u Novom Sadu, Srbija

\section{LIŠENJE SLOBODE OSUMNJIČENOG U PREDISTRAŽNOM POSTUPKU U REPUBLICI SRBIJI}

REZIME: Pravo na slobodu je prema članu 27, stav 1 Ustava Republike Srbije zajemčeno svim domaćim i stranim licima, što proizilazi iz ustavnog određenja da je titular ovog prava "svako". Svako ima pravo i da se slobodno kreće, nastanjuje u Republici Srbiji, da je napusti i da se u nju vrati. Ova sloboda može biti ograničena zakonom ako je to neophodno radi vođenja krivičnog postupka, zaštite javnog reda i mira, sprečavanja širenja zaraznih bolesti ili odbrane Republike Srbije (Ustav Republike Srbije, 2006, član 39 stav 2). Lišenje slobode dopušteno je samo iz razloga i u postupku koji su predviđeni zakonom. Lišena slobode mogu biti i maloletna i punoletna 
lica. Lice koje nije navršilo 14 godina, odnosno dete ne može biti lišeno slobode u predistražnom postupku jer prema našem pozitivnom pravu deca ne podležu krivičnoj odgovornosti. Cilj rada biće proučavanje kocepta lišenja slobode koje se vrši hapšenjem i/ili zadržavanjem osumnjičenog lica u predistražnom postupku prema pozitvnom krivično-procesnom zakonodavstvu Republike Srbije, sa zapažanjima iz dosadašnje prakse u radu i predlogom za neka zakonska poboljšanja.

Ključne reči: hapšenje, zadržavanje, policija, javni tužilac, rešenje o zadržavanju.

\section{References}

1. Advokatska komora Srbije - Informacija o početku rada Kol centra Advokatske komore Srbije za dodeljivanje branilaca po služebenoj dužnosti [Serbian Bar Association - Information on the beginning of operation of the Call Center of the Serbian Bar Association for the assignment of ex-officio defense counsel], No. 127/19 from 14.02.2019. Downloaded 2020 February 21, from https://aks.org.rs/aks/wp-content/ uploads/2019/02/SAJT-PO\%C4\%8CETAK-RADA-KOL-CENTRAAKS.pdf

2. Bejatović, S. (2016). Krivično procesno pravo: prema Zakoniku o krivičnom postupku iz 2011. godine [Criminal procedural law: According to the Criminal Procedure Code from 2011]. Beograd: JP Službeni glasnik

3. Bošković, A. \& Pavlović, Z. (2017). Zadržavanje osumnjičenog lica u krivičnom procesnom zakonodavstvu Republike Srbije sa osvrtom na pojedina uporedno pravna rešenja [Detention of a suspect in the criminal procedure legislation of the Republic of Serbia with reference to certain comparative legal solutions]. Vojno delo, 69 (5), pp. 126-139. DOI: 10.5937 / vojdelo1705126B

4. Duzlevski, I. \& Pantelić, N. (2020). Priručnik za krivični postupak: sudska praksa, objašnjenja, obrasci, primeri i šema krivičnog postupka sa više od 530 sudskih odluka i interaktivnom šemom postupka i obrascima na CD-u [Criminal Procedure Manual: Case Law, Explanations, Forms, Examples and Scheme of Criminal Procedure with more than 530 Court Decisions and Interactive Scheme of Procedure and Forms on CD]. Beograd: JP Službeni glasnik

5. Evropski komitet za sprečavanje mučenja i nečovečnog ili ponižavajućeg postupanja ili kažnjavanja (CRT), (2007). Standardi CRT-a - Najbitniji 
odeljci Opštih izveštaja CRT-a [The most important sections of the CPT General Reports]. CRT/Inf/E(2002) 1-Rev. 2006, Strazbur: Savet Evrope

6. Ilić, G., Majić, M., Beljanski, S. \& Trešnjev, V. (2018). Komentar Zakonika o krivičnom postupku [Commentary on the Criminal Procedure Code]. Beograd: JP Službeni glasnik

7. Jovančević, N. (2015). Novo krivično procesno pravo: shodno Zakoniku o krivičnom postupku od 2011, [New criminal procedure law: According to the Criminal Procedure Code of 2011)]. Beograd: Dosije studio

8. Knežević, S. (2011). Ograničavanje lične slobode zadržavanjem osumnjičenog. [Restriction of personal liberty by detaining a suspect]. Zbornik radova Pravnog fakulteta, Novi Sad, 45 (1), pp. 167-182. DOI: $10.5937 / \mathrm{zrpfns} 1101167 \mathrm{~K}$

9. Majić, M. (2016). Krivično procesno pravo: praktikum za pripremu pravosudnog ispita [Criminal Procedure Law: Practicum for the Preparation of the Bar Exam]. Beograd: JP Službeni glasnik

10. Matijašević Obradović, J. (2016). Krivično procesno pravo: opšti deo [Criminal procedural law: General part]. Novi Sad: Univerzitet Privredna akademija u Novom Sadu

11. Matijević, M. \& Marković, M. (2013). Kriminalistika [Criminalistics]. Novi Sad: Pravni fakultet za privredu i pravosuđe u Novom Sadu

12. Pavlović, Z. (2015). Krivično procesno pravo II [Criminal Procedure Law II]. Novi Sad: Univerzitet Privredna akademija u Novom Sadu

13. Pravilnik o načinu i uslovima primene policijskih ovlašćenja prema maloletnim licima [Rulebook on the manner and conditions of application of police powers towards minors]. Službeni glasnik $R S$, no. 83/19

14. Pravilnik o policijskim ovlašćenjima [Rulebook on police powers]. Službeni glasnik RS, no. 41/19

15. Škulić, M. (2017). Krivično procesno pravo: prema Zakoniku o krivičnom postupku iz 2011. godine [Criminal procedural law: According to the Criminal Procedure Code from 2011]. Beograd: JP Službeni glasnik

16. Ustav Republike Srbije [Constitution of the Republic of Serbia]. Službeni glasnik $R S$, no. 98/06

17. Vrhovni kasacioni sud - Odgovori Krivičnog odeljenja Vrhovnog kasacionog suda na sporna pitanja nižestepenih sudova sa sednice održane 04.04.2014. godine [The answers of the Criminal Department of the Supreme Court of Cassation to the disputable questions of the lower courts from the session held on 04.04.2014.] Downloaded 2020 February 10, from https://www.vk.sud.rs/sites/default/files/attachments/3\%20 KO\%204.04.2014..pdf 
18. Zakon o obligacionim odnosima [Law on Contracts and Torts]. Službeni list SFRJ, no. 29/78, 39/85, 45/89 - decision USJ and 57/89, Službeni list SRJ, no. 31/93, Službeni list SCG, no. 1/03 - decision USJ and Službeni glasnik $R S$, no. $18 / 20$

19. Zakon o policiji [Law on Police]. Službeni glasnik $R S$, no. 6/16, 24/18 and $87 / 18$

20. Zakon o ratifikaciji Konvencije o sprečavanju mučenja i nečovečnih ili ponižavajućih postupaka i kažnjavanja, izmenjene i dopunjene Protokolom 1 i Protokolom 2 uz Konvenciju, [Law on Ratification of the Convention for the Prevention of Torture and Inhuman or Degrading Treatment or Punishment, as amended by Protocol 1 and Protocol 2 to the Convention]. Službeni list SCG-Međunarodni ugovori, no. 9/03

21. Zakon o ratifikaciji Opcionog protokola uz Konvenciju protiv torture i drugih surovih, neljudskih ili ponižavajućih kazni i postupaka [Law on Ratification of the Optional Protocol to the Convention against Torture and Other Cruel, Inhuman or Degrading Treatment or Punishment]. Službeni list SCG-Međunarodni ugovori, no. 16/05 and 2/06 and Službeni glasnik $R S$-Međunarodni ugovori, no. 7/11

22. Zakonik o krivičnom postupku [Criminal Procedure Code]. Službeni glasnik $R S$, no. 72/11, 101/11, 121/12, 32/13, 45/13, 55/14 and 35/19

23. Zaštitnik građana - Inicijativa za dopunu Zakonika o krivičnom postup$\mathrm{ku}$ [Protector of Citizens - Initiative to amend the Criminal Procedure Code] no. 15-32-12/2017, reg. no 42557 from 20.11.2017. Downloaded 2020 February 10, from https://www.ombudsman.rs/index.php/ zakonske-i-druge-inicijative

24. Zaštitnik građana - Mišljenje o predlogu Pravilnika o policijskim ovlašćenjima [Protector of Citizens - Opinion on the Proposal of the Rulebook on Police Powers] no. 4110-20 / 2019, part. no. 12154 dated 22 April 2019. Downloaded 2020 February 10, from https://www.ombudsman.rs/ index.php/2011-12-11-11-34-45

25. Živanović, K. S. (2018). Ograničenje slobode kretanja osumnjičenog u predistražnom postupku [Restriction of freedom of movement of the suspect in the pre-investigation procedure]. Zbornik radova Pravnog fakulteta, Novi Sad, 52 (2), pp. 775-798. DOI: 10.5937 /zrpfns52-18841 